\title{
Linhas de Força da História dos judeus em Portugal das origens a actualidade
}

\author{
María José Ferro Tavares
}

\section{ORIGENS}

A presença de judeus em território português remonta ao século $v$, graças ao achado, em Mértola, de uma lápide funerária com o motivo do candelabro de sete braços e com a indicação do ano de $482^{1}$. Ainda pertencentes ao período visigótico são as duas conhecidas lápides, encontradas em Espiche, perto de Lagos, e datadas do século vi.

Documentada assim a sua existência, podemos deduzir que ela se prolongou durante o domínio islâmico, apesar de não se encontrar, até hoje, referenciada em textos escritos ou arqueológicos.

A reconquista cristã para sul permitiria que as influentes comunidades judaicas que habitavam o centro e o sul da Península Ibérica muçulmana, passassem para o poder dos novos senhores, os reis cristãos. O mesmo aconteceu na faixa mais ocidental, pois a mais antigas informações mencionavam um membro da família ibn Yahia, Yahia ben Yaisch, como colaborador do primeiro rei de Portugal, D. Afonso Henriques. Ao lado deste, participou na luta contra o Islão pelo que, segundo a tradição genealógica desta família, o soberano ter-Ihe-ia permitido o uso de brasão com a cabeça de um negro, como recompensa pela sua bravura. Daí, o facto de os Ibn Yahia serem também designados por Negro.

No entanto, é possível que a posse de um emblema por esta família seja mais recente, se atendermos a que as armas das linhagens da no-

Díaz Esteban, F., «Lápidas judías en Portugal», in Estudos Orientais II. O legado cultural de judeus e de mouros. Instituto Oriental, U.N.L., 1991, págs. 210-214. 
breza portuguesa só se iriam cristalizar nos séculos XIII-XIV e que dificilmente uma família judaica se sobreporia a esta. Porém, não podemos esquecer que os Negro constituiram a mais antiga família de judeus cortesãos que conhecemos e onde foram escolhidos vários rabis mores de Portugal.

\section{AS COMUNAS}

Por razões de segurança e de vida colectiva, as comunidades judaicas localizaram-se sempre nos centros urbanos, independentemente de uma ou outra família poder residir nas zonas rurais.

A comuna cujo centro era a sinagoga, erguia-se no espaço múnicipal e tinha a sua existência conferida pela concessão de uma carta de privilégios, onde se encontravam nomeados todos os seus usos, costumes, e liberdades. A permissão para abrir ou construir uma sinagoga era dada a um mínimo de dez famílias, residentes numa localidade, pelo rei com o beneplácito do bispo, uma vez que a religião moisaica era tolerada na cristandade, com o objectivo de os seus crentes poderem vir a converterse ao cristianismo.

$\mathrm{Na}$ carta de privilégios encontravam-se referidos os direitos e os deveres dos membros da comuna que podemos sintetizar do seguinte modo: afirmação da sua dependência directa em relação ao rei, seu único senhor; declaração de naturais do reino; permissão para livremente poder praticar a sua religião, língua e direito, este último inserto no Talmud; declaração da autonomia administrativa, jurídica e fiscal perante o concelho cristão e os seus oficiais, através da possibilidade de eleger os seus próprios magistrados entre os correligionários mais aptos para o desempenho dos mesmos; autorização para poderem circular livremente pelo reino, adquirir bens móveis e de. raiz, urbanos ou rurais, fazer contratos com cristãos e mouros, naturais e estrangeiros e exercer, semqualquer espécie de restriçcões, toda a actividade lícita; especificação dos tributos que deviam pagar à coroa (peitas, serviço real, incidindo este sobre o indivíduo, os bens fundiários e móveis, rendimentos de trabalho e ensino), à comuna e ao concelho.

Até finais do século XIV, podemos juntar a estes direitos e deveres o de os judeus poderem ser declaracios vizinhos do concelho de onde eram naturais e onde tinham bens imóveis, desde que pagassem ao municipio cristão, o soldo de vizinhança, tal como os indivíduos pertencentes à maioria.

As mais antigas comunidades portuguesas foram, com toda a certeza, as de Lisboa, Santarém, Coimbra e Évora. As duas primeiras e a última 
tiveram um crescimento populacional digno de menção, ao longo dos séculos XIII e XIV.

Os judeus ocuparam inicialmente o espaço cristão, próximo da Rua Direita ou de uma das portas do concelho. avizinhando lado a lado com cristãos, quer nas suas lojas e tendas, quer nas suas casas. O estabelecimento da sinagoga, casa de oração, escola, câmara de vereação e tribunal, congregou-os em redor desta casa e da sua rua.

A judiaria, a rua ou o bairro dos judeus, foi inicialmente sinónimo de comuna e, depois, de bairro apartado e como tal se fixaria, a partir da segunda metade do século XIV.

\section{O RABI MOR E OS OFICIAIS DAS COMUNAS}

Remonta a D. Afonso Henriques a existência de um rabi mor dos judeus portugueses. Os primeiros detentores do cargo foram os Ibn Yahia ou Negro, a quem já fizemos referência. Muito provavelmente constituiram o que poderiamos designar uma dinastia de rabis mores vitalícios, até à morte de Guedelha, no início do reinado de D. Pedro I, ou seja, no início da segunda metade do século XIV, altura em que os Negro seriam substituídos por dois imigrantes: Moisés Navarro, cuja família veio para Portugal no reinado de D. Dinis, e Juda Aben Menir, também natural de Navarra ${ }^{2}$. Negro seriam, de novo, os do9is últimos rabis mores vitalícios de Portugal, Guedelha e seu filho, Abraão, que ocupou o arrabiado mor até à sua extinção e desagregação noutros cargos, em 1463.

Este cargo era ocupado por um judeu cortesão da estrita confiança dos monarcas, generalmente seu físico, rendeiro ou gestor das finanças do reino, quer nas funções de almoxarife mor do reino ou de tesoureiro mor do reino. No desempenho das suas funções de gestão financiera, alguns destes judeus, como Juda Aben Menir, no reinado de D. Fernando, tiveram assento no conselho régio, não por direito próprio, mas por inerência do cargo de tesoureiro mor do reino, o que provocaria acesas críticas por parte da burguesia cristã.

O poder e açcão do rabi mor é-nos conhecido por documentos de finais de Trezentos, emitidos por D. Fernando e por D. João I, que no-lo permitem definir como o corregedor na corte para os judeus e seu re-

2 Sobre os Menir, veja-se: LeROY, Béatrice, Les Menir. Une famille sepharade a travers les siècles (XII-XXème siècles). Paris, C.N.R.S, 1985. 
presentante directo junto do soberano. Possuia a sua própria chancelaria -que, infelizmente se perdeu, assim como a das comunas-, ouvidores, tabeliães gerais, tabeliães e escrivães que o acompanhavam, sempre que se deslocasse com a corte ou só.

Tinha direito ao uso de um selo específico, selo do rabi mor de Portugal, com que autenticava todos os documentos emanados da chancelaria do arrabiado mor. Possuia cadeia própria que o acompanhava, com o respectivo carcereiro, quando das suas deslocações pelo reino.

Cabia-lhe convocr as assembleias plenas (cortes) dos súbditos judeus do rei de Portugal, a pedido deste e sempre que este desejasse ouvir as comunas, pela voz dos seus procuradores, sobre assuntos diversos, generalmente de natureza económica e fiscal.

Em 1643, o arrabiado mor vitalício foi extinto e desagregado em bários cargos, entre os quais o de contador na corte para os judeus. Mestre Abraão Negro, o último rabi mor de Portugal, foi também o primeiro contador. Mestre Abet, alfaiate de D. João II, era o contador mor, quando da expulsão dos judeus, em 1496, por ordem de D. Manuel.

A frente das comunas, encontravam-se os rabis menores, eleitos por sufrágio dos seus correligionários ou nomeados pelo soberano, por anos ou vitaliciamente. Em número de dois, tinham a coadjuvá-los o corpo de vereação da câmara, composto pelos homens bons da comuna eleitos, pelo tesoureiro e outros oficiais.

As comunas mais ricas possuiam ainda o doutor da Lei que nelas ensinava, os rabis das escolas das crianças, o capelão ou hazazan, cujos números variavam consoante o número de escolas e de sinagogas existentes.

\section{O AUMENTO DEMOGRÁFICO}

É muito difícil de quantificar a população judaica portuguesa. No entanto, se a colocarmos em paralelo com a minoria moura, somos obrigados a concluir que ela se apresentaba com uma maior densidade demográfica e com uma tendência sempre contínua para crescer. Este facto é facilmente observado pelo aumento do número de comunas e de judiarias, no reino, assim como pela expansão, no espaço cristão do concelho, dos seus bairros. Podemos afirmar que, entre os finais de Trezentos e a data da expulsão, a população judaica quintuplicou o número das suas comunidades que de, cerca de 30, passaram a cerca de 150.

Este crescimento populacional é explicado pelas imigrações, provocadas pelas expulsões ocorridas noutros reinos cristãos, como a Inglaterra 
e a França de que nos ficou a memória nos apelidos Inglês e Francês ou Franco e, sobretudo, pelas vicissitudes porque passaram os individuos da minoria nos reinos de Aragão/Catalunha e Castela, durante o século XIV, que motivariam a deslocação temporária ou definitiva para Portugal.

A comprovar esta imigração encontra-se a onomástica de origem toponímica, como, por exemplo, Catalão, Navarro, Aragonês, Castelçao, de Nájera, de Valença ou Valencim, Sevilhano, Toledano, etc., onde o verdadeiro apelido judaico da família foi substituído pelo da indicação de proveniência.

Outra explicação possível do aumento demográfico residia na constituição da própria família, onde um elevado número de filhos conseguia atingir a idade adulta. De facto, contrámos agregados familiares com mais de dez filhos, andando a média pelos $4 / 5$ filhos por casal. Raros eram os lares onde o número de filhos era diminuto, um ou dois, e neste caso a família era rica, pelo que havia um património que se procuraba fragmentar ao mínimo.

Assim, podemos afirmar que a imigração de Trezentos, a grande prole e os descobrimentos portugueses contribuiram para o seu crescimento demográfico que, em finais do século $\mathrm{XV}$, deveria rondar os 30.000 indivíduos, espalhados por todo o reino com especial incidência em Lisboa, Évora, Porto e Santarém, as quatro maiores comunas portuguesas.

Esta população de judeus portugueses viu-se, subitamnte, perturbada e atingida pela instabilidade social provocada pelo édito de expulsão dos judeus castelhanos, em 1492.

Com autorização de D. João II e contra a opinião do conselho régio e dos povos, aqueles puderam utilizar, na sua maioria, Portugal como lugar de passagem para o norte de África ou para as cidades italianas; outros, as designadas «600 casas» ou famílias receberam permissão para permanecer no reino. De um momento para o outro, a população judaica duplicou senão triplicou, trazendo consigo consequências graves para a minoria de origem portuguesa.

\section{A SEGREGAÇÃO}

Entendidos desde o início como naturais do reino e vizinhos do município cristão, onde residiam, os judeus portugueses participavam nas regalias que advinham destes direitos e relacionavam-se em franca e aberta convivência pessoal e colectiva com os vizinhos critãos ou as autoridades municipais. A presença de uns e outros nas festas privadas ou 
públicas da comunidades religiosamente estranha era frequente, mesmo em Lisboa, até ao início do século XV. A diferença religiosa não dera ainda lugar a uma segregação assumida por ambas as partes.

No entanto, a separação começara já a ser exigida, quer pelo clero, quer pela autoridade real. O primeiro protesto surgiu-nos no reinado de D. Dinis, pela voz do clero, que se queixou ao papa de que o rei de Portugal não cumpria o disposto no $4 .^{\circ}$ concílio de Latrão, no que respeitava à imposição de uso de sinais distintivos por parte dos indivíduos da minoria.

Estes só iriam ser coagidos ao porte do sinal, en meados do século $\mathrm{XIV}$, no reinado de $\mathrm{D}$. Afonso IV, certamente por consequência do clima de insegurança, provocado pela peste negra.

Embora não conheçamos nenhum documento legislativo contemporâneo do acontecimento nem tenhamos notícias de qualquer questão social antijudaica, a tradição escrita portuguesa fez remontar ao governo deste monarca o uso de sinal (um selo reondo no exterior do vestuário) que D. João I, em finais de Trezentos, substituiria por uma estrela de seis pontas.

A segregação física seguiu-se a exclusão espacial. Numa tentativa de conter as relações demasiado íntimas entre indivíduos de sexo e religião diferentes, sobretudo quando um dos interenientes era mulher e cristã, D. Pedro I, em 1366, proibia a deslocação destas à judiaria e determinava o encerramento do bairro judaico de Lisboa. Durante a segunda metade do século XIV, algumas das judiarias mais populosas foram sendo fechadas por portas que se abriam ao nascer do sol e se fechavam ao anoitecer, ficando os judeus proibidos de pousar nas casas cristãs, excepto nos lugares onde não houvesse comunidade judaica.

No entanto, as exigências dos procuradores dos concelhos nas cortes e as diversas cartas régias, promulgadas ao longo de Trezentos e Quatrocentos, permiten-nos concluir que a segregação não se executou totalmente. De facto, comunidades houve, como Lamego. Viseu ou Covilhã, que só tiveram os seus bairros fechados, nos meados do século xV, enquanto o uso do sinal não era exigido pelas próprias autoridades cristãs.

Ao não cumprimento da lei, juntava-se também a excepção por vontade régia, por solicitação de um concelho ou de um poderoso laico ou religioso, através da concessão de uma carta de privilégio. Assim as isenções do porte de distintivo, tal como as permissões para habitar entre os cristãos, forman frequentemente concedidas, até que a instabilidade do clima social as veio restringir e interditar. O mesmo aconteceu com o uso de 
vestuário e de adornos de luxo, com o porte de armas ou o transporte em mula com sela e freio, definidores de condição social superior.

Estávamos no reinado de D. João II (1481/1495) e as relações de convivência entre cristãos e judeus caminhavam para a ruptura, devido ao grande peso social, político e económico de um importante grupo de judeus cortesãos e à concorrência e rivalidade económica, provocada pelo crescimento de uma burguesia cristã mercantil, assim como pela afirmação profissional dos artesãos.

\section{CRISTÃOS E JUDEUS: O ANTIJUDAISMO}

O antijudaísmo apresenta-se na história portuguesa como uma manifestação tardia e sem representatividade específica, a julgarnos pela tradição, pela documentaçao escrita e pela imagem.

A tradição refere, para os séculos XIII, três profanaççoes da Sagrada Partícula: duas nas sinagogas de Coimbra e Estremoz que teriam posteriormente dado origem às igrejas da invocação do Corpo de Deus, facto comum noutras regiões da cristandade occidental, e a terceira em Santarém. No que respeita a Coimbra, a tradição e a documentação e a documntação escrita não coincidem totalmente, pois em finais do século XIV existiam a sinagoga velha e a igreja do Corpo de Deus, o que nos faz interrogar sobre o acontecimento que deu origem à tradição oral.

Em Santarém, a história da profanação é-nos transmitida a partir de um texto do século XVIII que nos fala das sanções que tiveram o judeu profanador e a mulher cristã, sua colaboradora, além do milagre que ocorreu. $\mathrm{Na}$ memória destes sacrilégios não se registou a destruição das comunidadesw judaicas, ocasionada por eventuais levantamentos populares.

Aliás, a mais antiga referência escrita a uma união popular antijudaica pertenceu ao reinado de $D$. Fernando, ou seja, a finais do século XIV e teve lugar em Leiria, durante a Semana Santa. No dia de Quinta Feira Santa, a comuna teve as suas casas apedrejadas por algum povo e rapazes o que levaria o seberano a aconselhar o encerramento das portas da judiaria, durante este período litúrgico cristão, para evitar no futuro maiores danos às pessoas e bens dos judeus.

Durante a crise política e social de 1383/1385, também o povo miúdo de Lisboa tentou assaltar a judiaria grande da cidade e as casas dos ricos judeus cortesãos, partidários da Rainha Regente $D$. Leonor e do rei de Castela. No entanto, a tentatia foi prontamente evitada com a actuação do Mestre de Avis e de alguns fidalgos. 
O único levantamento contra os judeus portugueses com consequências graves para as pessoas e bens destes, ocorreu em Lisboa, pelo Natal de 1449, numa altura em que a corte estaba ausente. Interpretado como acontecimiento estranho «e nunca visto» em Portugal, as autoridades régia e municipal reagiram castigando duramente os intervenientes neste motim contra os judeus.

De difícil interpretação pois surgiu como resposta espontânea a uma altercação violenta entre alguns indivíduos da minoria e uns rapazes critãos, a verdade é que podemos ver nele o início dos primeiros sinais de ruptura na convivência pacífica entre as gentes dos dois credos, sobretudo, na quebra de relacionamento entre o povo miúdo de Lisboa e os membros da respectiva comuna, alguns deles judeus cortesãos e ricos.

Poderemos igualmente interrogarmo-nos se estas mudanças nos comportamentos colectivos teriam algo a ver com o reflexo, em Portugal, dos acontecimientos ocorridos em Castela contra judeus e conversos.

Como acontecimento espontâneo e único na história dos judeus portugueses até à sua expulsão, em 1496/1497, ficou este levantamento de Lisboa de 1449. Isto não significa que, durante a segunda metade do século $\mathrm{xv}$, esta minoria não tivesse sentido crescer contra si um aumento de agressividade, expressa nas vozes e nas reivindicações dos procuradores nas cortes ou nas palavras mais inflamadas de um pregador. No entanto, o crescimento da rivalidade económica nunca teve qualquer consequência física, a não ser tornar consciente um sentimento de insegurança e de instabiidade social, que levaria as comunas do reino a pedir a $\mathrm{D}$. Afonso $\mathrm{V}$, a confirmação das bulas papais de proteçcão às pessoas e bens da minoria, no início da década de Sessenta.

A rivalidade económica no comércio, na banca e no artesanato levava a que aos protestos contra a usura do século XIV, se juntassem na centúria seguinte as queixas contra as sociedades comerciais e financeiras mistas de cristãos e judeus, contra o comércio marítimo internacional praticado por estes últimos, acrescidas da exigência de lhes impôr a judiaria como o espaço único de trabalho.

Ao contrário do que sucedeu nos reinos vizinhos da Península e em França, durante a permanência do povo judaico, pouco sabemos sobre a controvérsia religiosa e os escritos originais de apologética. De facto, - que conhecemos diz respeito às livrarias dos mosteiros, como o de Alcobaça, onde existia um ou outro manuscrito de polémica religiosa, cópia de obras produzidas em França ou nos reinos peninsulares, durante o século XIII, ou à obra de Álvaro Pais, bispo de Silves. 
O único texto escrito por um converso portuguès, ex-rabi de Tavira, mestre António, afilhado de D. João II, intitulava-se Ajuda da fé e era, segundo Révah, uma cópia truncada da obra de Jerónimo de Santa Fé, mas sem a agressividade antijudaica desta.

No entanto, seria incorrecto afirmarmos que não existia antijudaísmo em Portugal. Se este não estava presente na generalidade das relações quotidianas, ele circulava subrepticiamente no inconsciente colectivo do povo, traduzindo-se por certas atitudes insultuosas contra os membros da minoria. Como tal podemos ver o apelativo "cão" ou "perro judeu», ou certas festas populares no dia de Sto. Estêvâo, como a caça ao «porco pisco", o judeu.

A literatura medieval não foi antijudaizante em Portugal. Nas cantigas de escárnio o judeu encontrava-se praticamente amisso, com a excepção da referência a mestre Josepe e aos seus judeus colectores de impostos. Em Fernão Lopes, ele surgia-nos minorizado em relação e, em certos aspectos, na mesma categoria de ser inferior ou excluído que as prostitutas. Seria já no século xVI que o antijudaísmo se manifestaria por meio da palavra escrita na literatura, com Gil Vicente, João de Barros ou mesmo em alguma poesia cortesã, inserida no Cancioneiro Geral de Garcia de Resende.

Igual ausência da figura do judeu, com as suas características de diferença, se encontra na arte portuguesa. Apenas na sé de Évora, templo de forte marca estilística francesa, nos surge o rosto de um judeu com as suas longas barbas e a coifa cónica. Outra representação posterior - de finais do século XIV-, na pintura em madeira de Colegiada de Santa Maria de Guimarães, apresenta-o vestido de escuro e com um pequeno chapéu redondo na cabeça acompanhado por uma mulher. Ambos eram símbolos do mal para o homem medieval. Nos livros iluminados de Sta. Cruz de Coimbra, a coifa cónica ou o chapéu ponteagudo, à moda da Europa central, retratavam o judeu, de tal modo que nos é difícil dizer se tais representações não seriam importadas.

O século xv ofereceu-nos uma caricatura de um indivíduo da minoria com o seu barrete cónico e o nariz adunco, desenhada num dos livros da chancelaria de $\mathrm{D}$. Afonso $\mathrm{V}$, características que se viriam a repetir na pintura dos pintores "primitivos portugueses» $e$ dos do século XVI. De resto, a arte deu-nos a imagem de profetas com o rolo da Lei, com ou sem chapéu cónico. Os símbolos segregacionistas, a roda ou a estrela, não nos aparecem representados na arte medieval portuguesa que chegou até nós. 


\section{A ECONOMIA}

Ao contrário do que ocorreu noutros reinos da cristandade, os judeus portugueses puderam dedicar-se à agricultura, quer como grandes proprietários absentistas, quer como médios e pequenos proprietários rurais. Entre os primeiros, encontramos algumas famílias de judeus cortesãos, como os Ibn Yahia, o rabi mor Moisés Navarro, instituidor do primeiro morgadio pertencente a indivíduos da minoria, Isaac Abravanel e outros.

Utilizados pelos reis de Portugal no povoamento do reino, eles foram muitas vezes compelidos à aquisição de terras nos lugares onde se fixaram. Os judeus de Bragança compraram propriedades na região, no tempo de D. Dinis (séculos XIII-XIV), no valor de 3.000 maravedis de ouro, para o plantio de vinhas.

O cultivo de videiras foi bastante corrente entre os judeus, quer para a produção do chamado "vinho judengo", consumido nas casas e nas tabernas das judiarias, quer para a exportação. Importante era também a existência de pomares que, no Algarve, visava a exportação de frutas secas, de olivais e de herdades de cereais. Eram também conhecidos criadores de gado miúdo.

No entanto, a agricultura não era a base da economia do agregado familiar judaico, como acontecia entre a maioria dos cristãos. Por isso, estes. nas cortes de Trezentos, se agravavam aos monarcas de que os judeus não aplicavam o seu capital na produção agrícola.

De facto, uma parte importante da riqueza judaica era investida no empréstimo a juro, nos arrendamentos dos direitos reais, senhoriais e eclesiásticos, apesar de, neste último caso, tal ser interdito por direito canónico, no comércio e no artesanato.

Encontramo-los integrados no comércio regional e local, quer como almocreves quer como pequenos mercadores que percorriam as diversas feiras regionais, vendendo e comprando, enquanto, em casa, a mulher e o resto da família mantinha aberta a loja ou a tenda inserida no pequeno comércio da localidade onde habitavam, e frequentada quer por judeus, quer por cristãos. Por vezes, estas lojas e tendas extravasavam o espaço da judiaria e abriam-se na praça grande, como em Évora, ou na rua Direita do concelho, como em Santarém.

Outros, os ricos mercadores cortesãos dedicavam-se ao comércio por grosso e só indirectamente praticavam o comércio a retalho. Frequentavam as feiras nacionais, mas sobretudo as da Península e da Europa e chegavam com as suas mercadorias ao paço real, ao castelo ou aos mosteiros e sés. Residiam, na sua maioria, em Lisboa, onde firmavam 
sociedades com os grandes mercadores cristãos, nacionais e estrangeiros, nomeadamente italianos e flamengos.

Os descobrimentos portugueses permitiram a uma minoria de judeus privilegiados, ligados ao rei, a D. Henrique ou à casa de Bragança, penetrar no comércio ao longo da costa de África ou nos monopólios négios do trato africano ou do açúcar madeirense, exportando-os para o Mediterrâneo ou para Antuérpia.

A grande maioria da população judaica dedicava-se ao artesanato: ourives de ouro ou de prata, moedeiros da Casa da Moeda, aferidores de metais preciosos, ferreiros, latoeiros, alfagemes, armeiros, alfaiates, tecelóes, sirgueiros, marceiros, iluminadores, douradores, sapateiros, curtidores, etc.

No entanto, nenhum deles era homem de um só ofício, juntando à produççao oficinal, a venda directa na loja ou tenda e a venda ambulante. A estas actividades acrescentava-se ainda o empréstimo de dinheiro a juro o que provocava as queixas contra a usura praticada pelos judeus, ou o investimento monetário nos diversos lanços de arrendamentos.

Entre os judeus abastados, encontramos a dupla ocupação com fins lucrativos. Uns eram ricos mercadores e financeiros da coroa e das grandes famílias da nobreza ou do clero; outros eram médicos e notários que comerciavam e emprestavam dinheiro a juro.

\section{A CULTURA}

Junto à sinagoga, ou nela, funcionava, na comuna, a escola ou Bethamidrash. Era aí que as crianças judias aprendiam a ler e a escrever hebraico, língua que permaneceria como língua oficial da minoria, em todos os seus actos escritos até finais de Trezentos. D. João I iria exigir que, em todos os actos públicos escritos, os seguidores da Lei de Moisés usassem o português, determinação que viria a ser ratificada por $D$. Afonso $\mathrm{V}$.

Podemos assim dizer que os judeus eram, por força das circunstâncias, bilingues na fala e também na escrita. Utilizavam o português falado na sua convivência diária com os cristãos, usando uma linguagem penetrada de hebraísmos que Gil Vicente satirizaria, e o português escrito nos actos oficiais, a partir dos finais do século XIV; enquanto o hebraico se tornava uma língua interna, marcada pela região e pelos estudos rabínicos.

Se em todas as comunas existia uma escola, nem em todas havia o doutor da lei, o letrado. Aliás, uma das funções do rabi mor era a de zelar 
pela manutenção do ensino e da sua qualidade, nos lugares onde existiam as escolas, segundo podemos ler na legislavão do arrabiado mor, promulgada por D. João I.

Em Lisboa, sabemos da existência, durante o século $x V$, de vários locais de ensino para as crianças aprenderem a ler e a escrever o hebraico, como a escola de rabi Eliézer, ou para os jovens enveredarem pelo estudo dos textos rabínicos e de outros conhecimentos, como a que funcionava junto à sinagoga grande.

Esta última, em finais de Quatrocentos, dedicava-se ao estudo das ciências profanas pelo que Guedelha Palaçano, judeu cortesão à criação de um Estudo, designado por Estudo de Palaçano, para o ensino da ciência rabínica. Perto da sinagoga grande e destas Escolas, localizavase a Lvraria que, com a vinda dos judeus castelhanos para Portugal, vira crescer o número dos seus livros.

Escolas para crianças e para o ensino avançado do Talmud havia tambén em Évora, a segunda comunidade judaica mais populosa e importante do reino.

Infelizmente, sabemos muito pouco sobre a produção cultural dos judeus portugueses, ao contrario do que sucede com a dos judeus do resto da Península. Na sua grande maioria desapareceu, restando-nos, hoje, uma escassa vintena de manuscritos em hebraico, iluminados uns, outros não. Enterrados uns, com receio das autoridades cristãs, após a expulsão; queimados outros, mais tarde, quando apanhados pela Inquisição; vendidos no norte de África ou no Oriente aous judeus deswtas regiões, a verdade é que o que subsiste hoje da produção cultural dos judeus peninsulares pode incluir, sem que possa ser destrinçado por ignorância de local de produção, obras originárias dos judeus portugueses.

Sobre elas pouco sabemos, apesar de Aboab na Nomologia elogiar a escola de calígrafos existente em Portugal e de a mais antiga referência à posse privada de livros pelos indivíduos desta minoria remontar au reinado de D. Afonso IV, ou seja, a meados do séculko XIV. Apesar do pouco que conhecemos sobre a caligrafia e a iluminura hebraica, em Portugal, a verdade é que este mínimo conduziu a duas deses diametralmente opostas, como a de Gabrièlle Sed-Rajna e a de Thérèze Metzger.

Além da cultura autóctone da minoria, podemos afirmar que esta sofreu uma aculturação por parte da maioria cristã, bem visível na produção de poesia trovadoresca de que nos ficou a memória escrita de alguns poetas trovadores, como Samuel de Alcobaça, Vidal de Elvas e Judas Negro, trovador da rainha D. Filipa de Lencastre. De Vidal chegou-nos algumas cancccões de amor, dirigidas à "formosinha de Elvas" e integradas no Cancioneiro da Vaticana. 
Em finais do século XIV ou inícios do xV, a Crónica Geral de Espanha foi copiada em hebraico. Mas, mais uma vez a referência documental é indirecta, pelo que ignoramos o nome do tradutor e o do encomendador.

Entre os autores de obras jurídicas e filosófico-religiosas, destacaramse alguns membros da familia Ibn Yahia, Navarro e Abravanel. Além destes, figuram como encomendadores de livros alguns ricos mercadores e artesãos de Lisboa. As cópias incidiram sobre as obras de Maimónides, Kimhi, Nahamanides, além de textos bíblicos.

Na biblioteca de Lisboa e, talvez, na de Évora, assim como em certas casas particulares existiam, a par da Torah e de outros livros da Lei, escritos de autores rabínicos, obras de filosofia, matemática, astrologia, medicina, traduzidos para o hebraico por via do árabe. É provável que uma élite soubesse latim e tivesse estudado na universidade. Pelo menos, sabemos que Abraão Ibn Yahia, rabi mor de $D$. Afonso $V$ e seu médico, frequentou os Estudos Gerais de Coimbra, tal como o seu filho Guedelha.

A medicina, quer no seu campo clínico, quer cirúrgico, quer ainda na especialidade de oftalmologia, foi amplamente praticada pelos judeus portugueses, levando alguns deles ao serviço do rei e da sua família, da nobleza, do alto clero e do concelho cristão, apesar dos impedimentos previstos pela lei canónica.

Alguns agregaram aos conhecimentos médicos a observação astrológica, como sucedeu com mestre Guedelha Ibn Yahia, rabi mor, físico e astrólogo de D. João I, D. Duarte e D. Afonso V. Dele V. Duarte anotaria no seu Livro dos Conselhos o cálculo dos solestícios e equinócios e, certamente, também o cálculo das horas pela observação da estrela polar. Coube-Ihe como astrólogo predizer o reinado infeliz e curto de D. Duarte, com base na conjunção dos astros no dia da coroação régia, predição que seria anotada pelo cronista Rui de Pina.

Os judeus portugueses possuiram tipografía em caracteres hebraicos e latinos. Faro, onde Samuel Gacon editou o Pentateuco, foi a primeira. Seguiu-se-lhe Lisboa e Leiria. Nesta última, os Orta fizeram sair o Almanaque Perpétuo de Abraão Zacuto, traduzido, a pedido de D. João II, por mestre José Vizinho para o castelhano e o latim.

A produção artística dos judeus portugueses desapareceu na sua quase totalidade ou permanece desconhecida. Infelizmente, o terramoto de 1755 destruiu aquela que foi a maior e mais rica sigagoga portuguesa, tal como no início do século XVI, por razões que ignoradas, desapareceu a sinagoga de Évora. Ambas pela amplidão das suas naves e profusão de claustros deviam ter sido importantes como edifícios. A única que nos restou foi a de Tomar, construída nos meados do século XV. Na sua maio- 
ria, as casas de oração dos judeus eram habitações, transformadas em lugares de reunião e de oração. Assim aconteceu em Castelo de Vide ou na Guarda.

Ao seu desaparecimento, junta-se o desconhecimento dos seus arquitectos e da maioria dos seus benfeitores. No entanto, algumas das poucas lápides em hebraico que chegaram até nós, falam-nos de alguns nomes, como Juda, filho de Guedelha, rabi mor de D. Dinis, que teria mandado erguer a sinagoga grande de Lisboa, ou de D. Juda Aben Menir, rabi mor de $\mathrm{D}$. Fernando que teria ordenado a construção da sinagoga do Porto, cujo arquitecto foi o rabi José ben Arieh.

Além de arquitectos, os judeus portugueses foram ourives de reis e de rainhas, de membros da família real e de ordens religiosas, como os judeus Sapaio, ourives do duque de Beja, D. Manuel, e artistas das alfaias de ouro e prata que este ofereceu aoi convento de Cristo. lluminadores, douradores, ourives e argentários, na sua grande maioria, as suas obras caíram no anonimato se, porventura, chegaram até nós.

\section{OS JUDEUS PORTUGUESES E AS DESCOBERTAS}

Mais uma vez é o silêncio ou a escassa informação que paira sobre o papel dos judeus portugueses, no empreendimento das descobertas, impulsionado pelos reis de Portugal, a partir de inícios do século xv. A quase inexistente documentação nao impediu o aparecimento da tese de Joaquim Bensaúde, onde Ihes foi dado um papel de grande relevo, a que foram contrapostas outras mais comedidas como a de Jaime Cortesão.

A documentação régia é praticamente omissa sobre esta questão, se exceptuarmos uma ou outra carta a autorizar judeus peninsulares a embarcar nas caravelas portuguesas, com a finalidade de comerciarem em terras de negros.

Este facto leva-nos a concluir que os judeus portugueses tinham livre trânsito nestas viagens, tal como sucedia com qualquer mercador português, fosse cristão ou mouro. De facto, Zurara na Crónica dos feitos da Guiné referiu que, nas caravelas que partiram de Lagos, no tempo do infante $D$. Henrique, ia um judeu que viria a ficar como refém, juntamente com o mestre de uma das caravelas, num trato de resgate de mouros na ilha Tider, perto do cabo Branco. Este Judeu cujo nome e proveniência desconhecemos -embora possamos supôr que seria de Lagos-, ia certamente como mercador, ou seja, para o resgate de mouros e negros.

A sua actividade nas descobertas não os fez destacarem-se como navegadores, pois nenhum texto nos fala de vocação marítima da minoria 
judaica. Pelo contrário, é muito possível que a sua importância tivesse incidido mais na transmissão de informaçóes, dada a facilidade em viajar que possuiam, quer pela cristandade, quer pelo Islão.

Não nos esqueçamos da narrativa de viagem de Benjamim de Tudela ou do atlas do judeu maiorquino Abraão Crescas, de meados de Trezentos: nele podemos observar uma caravana de camelos com mercadores judeus, bem assinalados pelo seu chapéu bicudo à maneira da Europa central, a atravessar as estepes asiáticas.

Como informadores, foram utilizados por D. João II. José de Lamego e Abraão de Beja sabiam informações sobre Ormuz por onde o primeiro já andara, participando-as ao monarca, conforme nos diz João de Barros, na Década I. Por isso, o soberano enviou-os a saber notícias de Pero da Covilhã e de Afonso de Paiva. Enquanto José de Lamego se deslocou à Etiópia, Abraão de Beja foi até Ormuz e, daqui, percorreu o mar Vermelho e a Índia, para trazer a Portugal as informações pretendidas por D. João II.

Aliás, esta mesma função de espionagem e de embaixadores, quer em terras do norte de África, quer em terras do Grão Turco, veio a ser desempenhada, durante o século xvI, pelos judeus em diáspora por estas paragens, após a expulsão.

A sua participação na cartografia foi-nos referida pelos cronistas de Quinhentos. Assim Gaspar Correia, nas Lendas da Índia, mencionava a vinda de Jácome de Maiorca, para o serviço do infante de D. Henrique, o qual viria a ser, depois de muita celeuma, identificado com Jaffuda Cresques, filho de Abraão Cresques. Hoje, esta identificação é, de novo, contestada por Luis de Albuquerque com base na data de 1375 em que mestre Jácome assinou como Jaffuda Cresques e a data de 1430 em que teria vindo para Portugal.

Também João de Barros e Fernando Colombo referiram a participação de mestre José Vizinho, natural da Covilhã, na empresa científica das descobertas. De facto, D. João II enviara-o à Guiné para medir a altura do sol no equador. Este judeu participava com D. Diogo Ortiz e mestre Rodrigo, num conselho régio para o estudo do empreendimento dos descobrimentos. A ele deve ter sido agregado Abraão Zacuto, na década de 90 , pois dele conhecemos a ordem de pagamento de cinco moedas de ouro, mandada lavrar por aquele soberano e cujo recibo foi assinado em hebraico por ele. Estavamos no ano de 1493.

José Vizinho traduziu para castelhano e latim o Almanaque Perpétuo de Zacuto e as tábulas de declinação solar, que viriarn a ser editados em Leiria, na tipografia dos judeus Orta. 
Se pouco sabemos sobre a actuação dos judeus portugueses no movimento das descobertas, o mesmo já não sucede quanto à conquista norte africana, onde alguns conseguiram amplos privilégios como recompensa dos serviços prestados na luta contra os mouros. Mestre Abraão Ibn Yahia, rabi mor de D. Afonso V. viria a morrer na conquista de Arzila, servindo o rei com um grupo de judeus, seus criados, montados a cavalo.

\section{A EXPULSÃO E O BAPTISMO FORÇADO}

A vinda dos conversos castelhanos, durante o último quartel do século $\mathrm{XV}$, alguns deles perseguidos pela Inquisição, instalada em Castela em 1478 , agravada pela expulsão geral da minoria judaica pelos Reis Católicos, em 1492, desestabilizou completamente a sociedade portuguesa que via, em ambos, um perigo, quer religioso, quer económico.

O facto de alguns conversos procurarem voltar, em Portugal, ao judaísmo, iria obrigar $\mathrm{D}$. João $\|$ a actuar pelos seus próprios meios, ou seja, a criar um corpo de inquiridores da fé, ligados ao tribunal diocesano, depois de ter consultado a Sante Sé. Como resultado destas inquirições, alguns conversos vieram a ser queimados por hereges.

A esta instabilidade sócio-religiosa e à desconfiança crescente juntouse - medo à peste que provocaria uma reaçcão colectiva antijudaica, sobretudo, nos concelhos mais densamente povoados por judeus, a qual seria prontamente sufocada pelo rei e pelas autoridades municipais de Lisboa, Évora e Porto, pelo que não tiveram quaisquer consequências para as gentes das respectivas comunas. Curiosamente, estas cidades tinham as maiores comunidades de judeus portugueses e foram tambén as que receberam maior número de imigrantes castelhanos.

A presença clandestina de muitos destes conduzira à escravidão dos que não conseguiram ou não tiveram alguém que, por eles, pagasse o tributo de entrada em Portugal, ou seja, os oito cruzados de ouro. Para estes, o monarca promulgava o primeiro convite ao baptismo, a 19 de Outubro de 1492, acompanhado de asmplos privilégios sociais e fiscais. Este apelo foi seguido pela carta dos Reis Católicos de 10 de Novembro do mesmo ano, permitindo-lhes o regresso a Espanha como cristãos baptizados ou a baptizarem-se em cidades fronteiriças espanholas, e a tomar posse dos seus antigos bens.

Alguns fizeram-no, como o comprova a documentação publicada por Suárez Fernández. Outros viram os seus filhos menores serem baptizados e entregues a Álvaro de Caminha, capitão donatário de S. Tomé, que os levaria consigo para esta ilha atlântica, com a incumbência régia de os 
educar cristãmente, de os tornar proprietários de terras na ilha, senhores de engenho de açúcar e participantes do resgate de escravos na região.

.Com a morte de D. João II, D. Manuel, duque de Beja, tornouse rei de Portugal e uma das suas primeiras atitudes, para com os judeus, foi a de libertar os que tinham caído em servidão. Até Maio de 1496, as relaçóes entre a minoria judaica e a coroa foram normais e nada fazia prever o desfecho trágico de 5 de Dezembro do mesmo ano.

O desejo de casar com a princesa viúva de D. Afonso, Isabel, obrigálo-ia a usar os judeus como peões no xadrez da política peninsular que visava a unificação peninsular, sob a égide de uma das coroas. A anuência da filha mais velha dos Reis Católicos em se tornar rainha de Portugal passava pela exigência da expulsão de todos os «hereges», compreendidos aqui conversos e judeus, cuja presença era compreendida como a causa dos males e castigos divinos que tinham caído sobre Portugal, entre os quais se encontrava a morte do príncipe herdeiro e a repentina doença e falecimento de D. João II, além das pestes.

Sem a unanimidade do conselho régio, D. Manuel viria a decidir-se pela expulsão das minorias religiosas, existentes no reino: a judaica e a moura. Pelo édito de expulsão de 5 de Dezembro, judeus e mouros deviam abandonar o reirio até Outubro de 1497.

Sobre o que se passou nestes dez meses, pouco sabemos. Não desejando a partida dos judeus, o soberano procurava, através da confirmação de amplos privilégios sociais e fiscais e de pressões de ordem psicológica e outras, atraí-los a um baptismo. Como mecanismos impeditivos da saída, restringiu os portos de embarque e promoveu o seu baptismo forçado, por fases, començando pelos indivíduos mais jovens: crianças, adolescentes, adultos jovens.

Assim, no final da Quaresma de 1497, a 19 de Março, véspera de Domingo de Ramos — talvez a data da Páscoa judaica - mandou retirar as crianças judias aos pais, baptizá-las e entregá-las a famílias cristãs. Uma semana mais tarde, impunha o baptismo aos adolescentes e jovens menores de 25 anos e o baptismo a alguns adultos que se encontravam em Lisboa, para embarcar.

É o conhecido baptimos nos Estaus, onde os judeus se encontravam albergados e donde daíram em grupos para diversas igrejas da cidade, a fim de lhes ser imposta a água do baptismo.

A 30 de Maio, D. Manuel fazia um derradeiro apelo à conversão voluntária dos que ainda não se encontravam baptizados, através de uma carta régia de privilégios em que prometia. 
- não inquirir, durante vinte anos, sobre o comportamento religioso dos neófitos;

- em caso de denúncia, o seu processo devia seguir os trâmites do tribunal civil, com as trestemunhas publicadas, o que era o inverso do que ocorria nos tribunais inquisitoriais;

- em caso de culpa provada, os bens dos condenados por heresia seriam entregues aos herdeiros cristãos.

Este documento, sucessivamente, conformado por D. Manuel e por D. João III, em 1522, por mais dezasseis anos, pode ser definido como a «magna carta» dos cristãos novos portugueses, esgrimida por estes, em Roma, contra o Santo Ofício.

De Junho a Setembro de 1497, data da entrada, em Portugal, da princesa D. Isabel, ocorreram a partida dos judeus que se recusaram a abjurar a sua fé e o baptismo forçado, por todo o reino, dos judeus que não tinham conseguido vender todos os seus bens ou não chegaram, no tempo devido, ao local de embarque.

Em todo o território português, o édito foi cumprido. A única excepção permitida respeitaria às praças portuguesas do norte de África, conquistadas por D. Manuel, onde a existência de judiarias e de «judeus de sinal» foi consentida.

No entanto, apesar da existência do édito de expulsão das minorias religiosas, os «judeus de sinal», como os Benzamerro, os Rute, etc., continuaram a frequentar o reino e a sua corte e a comunicar com os cristãos novos, practicando o proselitismo religioso, junto destes. Em terras de Marrocos, estes judeus foram espiões e embaixadores ao serviço de Portugal.

\section{OS CRISTAÕS NOVOS}

Com o baptismo forçado da minoria judaica e a expulsão dos mouros, deu-se a unificação religiosa do reino, segundo os princípios que viriam a vigorar no estado moderno: a religião do príncipe é a religião do reino.

Os recém-baptizados eram agora designados por "cristãos novos", apesar de a carta de 30 de Maio ter proibido que fossem tratados «como gente distinta". Na nova realidade social encontrava-se ausente a onomástica judaica, substituída pela cristã, tal como desaparecera o espaço fechado da judiaria, agora designado por «Rua Nova» ou «Vila Nova».

Resirnados exteriormente, os neófitos regressaram às suas antigas casas, aos seus bens e à sua profissão, avizinhando no espaço que, antes, 
fora exclusivamente judaico, com os cristãos velhos, novos moradores das casas abandonadas dos que conseguiram partir.

A vizinhança próxima era uma forma de compulsão à integração. Pretendia-se com ela uma mais rápida conversão dos antigos judeus, mas também uma vigilância que lhes impedisse, no interior do lar, continuar a viver no judaísmo. Aqui os olhos atentos eram os dos criados, amas e serviçais cristão velhos, ou os escravos baptizados.

Alguns, cujo número é impossivel determinar, com um anterior passado cortesão ou de pertença a uma distinta família judaica, pelo facto de se terem convertido de livre vontade, foram nobilitados, outorgandolhes antes D. Manuel uma carta de limpeza da mancha do nascimento. A nobilitação continuaria a ser concedida, ao longo do século XVI, quer como recompensa por feitos praticados na guerra de África ou na Índia, sendo uma das vias de entrada a concessão do título de cavaleiro numa das ordens militares. A estes, aos fidalgos de solar, aos cavaleiros e escudeiros da casa real não thes era aplicada, nem à sua família, a designação de cristãos novos.

Com a mesma preocupação de integração, surgiu a lei manuelina que proibia os antigos judeus de se casarem entre si. Esta medida, que não viria a resultar numa parte substancial da população cristã nova, procurava promover o cruzamento de pessoas e bens dos dois grupos cristãos, de modo a caminhar para uma futura fusão dos dois corpos da sociedade e a uma maior assimilação do catolicismo, por parte do conjuge ex-judeu, e a uma educação cristã dos descendentes, através da vigilância permanente da família cristã velha.

No entanto, durante o século $\mathrm{xVI}$, este cruzamento só se veio a efectuar nos estratos sociais mais elevados que, por nobilitação efectiva e o esquecimento do seu passado judaico. Os estratos sociais médio e baixo da minoria cristã nova evitavam cruzar-se com os cristãos velhos, preferindo um isolacionismo, afirmativo do direito à diferença histórica.

Aos recém-baptizados abriam-se-lhes, agora, os cargos municipais, o ensino universitário, as funções no aparelho da administração central ou nos tribunais, a carreira eclesiástica, além da já referida carreira das armas, no norte de África ou na Índia. Por isso, os encontramos como sacerdotes, cónegos das sés, monges e freiras. Frequentavam as universidades, como a de Coimbra ou a de Évora, a de Salamanca ou a de Lovaina, onde se bacharelavam, licenciavam e doutoravam em direito, teologia, medicina. No século XVII, a universidade de Coimbra era tida como um centro forte da docência cristã nova, tal como no século xVI suspeita semelhante caíra sobre a de Salamanca, no reino vizinho. $O$ 
mesmo sucedeu com o exercício da medicina, uma vez que o corpo médico era, na generalidade, constituído por descendentes dos antigos judeos.

A nível económico, os cristãos novos mantiveram-se nas tradicionais profissões: artesanato e comércio. A grande maioria pertencia ao grupo dos artesãos e dos pequenos e médios mercadores. Os mais ricos continuavam ligados à alta finança e ao trato internacional, com a Europa e os novos mundos, além de lhes continuar a pertenecer o crédito aos monarcas portugueses e espanhóis. Estavam, neste caso, os Mendes que, desde o início do século XVI, apareciam fortemente ligados a Antuérpia e à compra de mercadorias diversas, entre as quais, a prata pra a Casa da Moeda de Lisboa.

É nesta conjuntura económica, alterada internamente pelo estabelecimento do Tribonal do Santo Ofício que devemos entender o fenómeno da diáspora dos cristãos novos portugueses. De facto, a grande mobilidade destes, quer para o velho continente, quer para os novos mundos do Atlântico e do Índico, deve ser entendida, sob duas vertentes: o desejo, para uns, de voltar à fé ancestral e, para outros, o apelo dos interesses económicos que os fazia olhar para certas regiões da Europa e para os novos mundos, provenientes das descobertas, como lugares onde livremente podiam ser judeus e enriquecer.

Por isso, na Europa, os seus interesses viraram-se para Antuérpia onde D. Manuel criara uma feitoria, e para as cidades italianas, centros importantes do comércio mediterrânico central e oriental. No final de Quinhentos, perante a decadência daquela, o polo de interesse mudava-se para Amesterdão e também para Hamburgo. Neste interland de rotas comerciais terrestres e marítimas europeias ficavam as cidades francesas, como Lyon, Bordéus, ou, nos finais de Quinhentos e inícios de Seiscentos, La Rochelle e Baiona, com S. João da Luz.

A América, quer espanhola, quer portuguesa, desde cedo os interessou: os metais preciosos na primeira, as plantaççoes e engenhos de açúcar na segunda a que não foi estranho, neste caso, o resgate de escravos de Angola para o Brasil, praticado por sociedades comerciais familiares com assento em Lisboa e sucursais em S. Tomé e no Brasil.

O Oriente exerceu também uma grande e dupla atraçcçao sobre as famílias cristãs novas que, cedo, se instalaram na Índia, comerciando e defendendo o império português no índico. No Industão, aos interesses económicos juntou-se a franca passagem para a ajuração, via Ormuz ou Golfo Pérsico, além da possibilidade de, longe, poder regressar ao convívio dos antigos familiares judeus, radicados em terras do Turco e à sua antiga religião, de uma forma velada mas mais segura de que no reino. 
Noutros, a atraçcão do Oriente levou-os a Malaca, à China e ao Japão.

\section{O ANTIJUDAÍSMO}

As representações mentais, sejam elas quais forem, pertencem à história da longa duração e, por isso, a sua mudança ocorre num tempo muito lento. Neste caso, encontra-se a imagem que a cristandade forjou para o judeu e, também, a que este criou para os indivíduos daquela. 0 cristão novo designava os cristãos velhos por «goim», enquanto estes o apelidavam de judeu herege.

Numa tentaitiva de afirmação histórica como povo, definido por uma religiáo e por uma tradição ancestral, os cristãos novos procuraram no hermetismo e na endogamia as razões da sua sobrevivência histórica e do seu direito à diferença, apesar da proibição legal que os caracterizava, depois do baptismo, como gente não distinta dos cristãos de origem.

Ao encerramento sobre si próprios correspondia a suspeita, por parte dos cristãos velhos, de práticas religiosas judaicas e da esperança na vinda do Messias. As acusações de criptojudaísmo começaram a avolumarse e a comunidade cristã de origem rejeitava os recém-convertidos por hereges.

Foi dentro deste clima psicológico a que se veio juntar a fome e a peste, assim como a ausência da corte de Lisboa, que ocorreu o massacre dos cristçaos novos, em 1506. As descrições desta tragédia foramnos transmitidas por cronistas portugueses de ascendência cristã e judaica, e por um anónimo alemão. Entre mil e quatro mil teriam sido as vítimas.

Pela primeira vez, materializava-se num levantamento popular de consequências graves para a minoria a consciencializaççao de um antijudaísmo no seio do povo miúdo, empolado e levado às últimas consequências pelas pregações inflamadas de frades mendicantes, neste caso, os de S. Domingos de Lisboa. Para $\mathrm{D}$. Manuel foi o primeiro sinal de que a integração pretendida podia falhar, de ambas as partes.

A partir deste momento a contenção para com os antigos judeus, por parte da maioria cristã velha, era difícil e o antijudaísmo enveredou por um crescimento galopante, durante o período moderno, com cristas de afirmavão volenta em períodos de crise social, política ou económica que se viriam a manifestar em uniões populares. A denúncia fácil de heresia, os escritos e panfletos antijudaicos, os sermões contra os falsos cristãos, as visitações diocesanas e as inquisitoriais, os autos públicos da fé, etc., exacerbaran este antijudaísmo a que não foi estranha a velha rivalidade 
social e económica, quer entre cristãos velhos e cristãos novos, quer entre estes últimos.

A Inquisição, como o seu clima de medo e de uma compulsão pela força de todo o comportamento religioso, social e cultural, entendido como anómalo ao padrão estabelecido pelo estado e pela lgreja, iria alimentar este ódio popular, entendêe-lo a outras franjas sociais que inicialmente lhe eram alheias e transformá-lo no sentir generalizado de quease todos os portugueses. A este sntimento colectivo não foram estranhos também os próprios cristãos novos, quando rejeitavam exteriormente os que se afirmavam pela diferença.

A segregaççao dos hereges era exigida para preservação da cristandade. A rejeição social viria a conduzir, paulatinamente, a partir da segunda metade do século XVI, à exclusão de certas funções a qual se veio a agravar com a dominação espanhola e durante o século xvII com as inabilitações para as honras, cargos eclesiásticos e universitários. Tentouse igualmente impedir que, pelo casamento, os cristãos novos continuassem a entrar na nobreza de linhagem. Para tudo passaria a ser necessária a carta-certidão de limpeza de sangue.

A esta exclusão social e mental contrapunha o doutor Fernando Cardoso, médico das cortes de Filipe III e Filipe IV, ou Isaac Cardoso, como viria a ser conhecido como jedeu, a obra apologética intitulada «As excelências dos Judeus».

A segregação da "gente de nação» viria, legalmente, a acabar, depois de muito combatida por jesuítas e alguns políticos dos séculos XVII e XVIII -que relacionavam a decadência de Portugal com a saída para outras regiões dos cristãos novos-, em 1773, com a abolição pelo Marquês de Pombal, primeiro ministro de D. José I, da distinção entre cristão novo e cristão velho.

\section{O CRIPTOJUDAÍSMO}

O criptojudaísmo foi definido como uma heresia pelos cristãos e foi rejeitado pelos judeus como urn judaísmo. Para os primeiros, o facto de os cristãos novos viverem exteriormente uma prática cristã, enquanto, no interior dos seus lares, a referência religiosa era a tradição judaica, levava à justificação do Tribunal do Santo Ofício como forma de combater esta heresia do seio da cristandade; para os segundos, a recusa de a minoria cristã nova em abandonar o reino, apesar das perseguições inquisitoriais, para poder regressar a um judaísmo pleno e livre, fazia-os rejeitarem-na como pertencente ao mundo judaico. 
Poderiamos dizer, muito simplesmente, que os criptojudeus não se integravam nem na cristandade nem no mosaísmo, pois encontravam-se excluídos, pelos seus comportamentos heterodoxos, de ambos os grupos.

No entanto, o criptojudaísmo não pode ser apenas entendido, como um questão religiosa. Ele era pelas suas ligações às raízes ancestrais do povo hebreu, a razão da sua afirmação histórica como nação distinta da cristã. A alteridade, o seu desejo à diferença, levá-los-ia a declararem-se pertencentes à «casta dos judeus». Quando muito pouco restava já da transmissçao fiel da religião moisaica, a memória revivida dessa ancestralidade era transmitida pelo sangue. Ser judeu era não ser cristão.

Se a integração exterior foi uma realidade, desde cedo, através da onomástica, da frequência da catenquense, da missa e dos sacramentos, a assumpção desse acto social e religioso só tardiamente se manifestaria.

De facto, no interior dos lares cristãos novos, a leitura dos Salmos sem a oração da Glória ao Pai, no final, era corrente, tal como a benção ao modo judaico, a rejeição dos alimentos proibidos pela Lei, o sabbat, os jejuns ou as Páscoas. Depressa algunas destas tradições religiosas foram, com o terror imposto pela Inquisição, caindo em desuso, sobretudo as mais visíveis, como o descanso sabático, o quipur, a $s$ Páscoas, ou os interditos alimentares. No entanto, permaneceriam os thanis ou junção do sabbat com a festa cristã de dedicação do sábado à Virgem Maria.

A transmissão desta tradição, feita pelo homem ou pela mulher, na frequente ausência daquele, exigiu o hermetismo e a endogamia e foi afirmação de alteridade. A designação de gente de nação que a maioria cristã the conferiu, acabaria por ser o reconhecimento público de que os descendentes dos antigos judeus, apesar de baptizados, preferiram o direito à diferença, não se integrando na sociedade cristã, a não ser por excepção.

\section{A DIÁSPORA}

O êxodo dos cristãos novos portugueses iniciou-se, a pesar da proibição, imediatamente após o baptismo forçado. Partiam clandestinamente para a Itália ou para o norte de África islâmico, lugares onde podiam viver livremente a sua fé ancestral.

Se D. Manuel, durante os primeiros anos, limitou a saída para o exterior do reino às famílias cristãs novas - não aos indivíduos, desde que aqui permanecessem os pais, a mulher e os filhos-, com a intenção de os coagir a um regresso e à integração na sociedade cristã velha, a verdade 
é que, perante o levantamento de 1506 contra os cristãos novos de Lisboa, o soberano decidia dar a oportunidade de abandonar o reino livremente aos que quisessem partir para outras terras, permitindo-Ihes a venda dos bens.

Assim, entre 1507 e 14 de Junho de 1532, os descendentes dos judeus puderam ir para outras partes da cristandade ou do Islão, com as suas famílias e riquezas, e regressar ao judaísmo.

Com intervalos, esta permissão ser-lhes-ia permitida. Assim sucedeu por altura dos perdões gerais de 1535 e 1547, intercalada pela proibição, durante três anos, para minorar as consequências económicas e sociais da sangria deste corpo activo. Em 1573, voltava-se a proibir a partida que seria restabelecida em 1577 e novamente revogada em 1580. Em 1601, os cristãos novos compravam ao rei de Espanha e de Portugal a liberdade de circulação, interdita de novo em 1610.

Algusn políticos defendiam, como única solução para o reino, a expulsão da minoria cristã nova herética e de suas famílias. Tal proposta nunca passou de projecto pois, a contrariá-la, tinha a voz dos opositores que viam êxodo um prejuízo para o país e, sobretudo, a dos próprios inquisitores.

Clandestina ou legalmente, os cristãos novos foram abandonando Portugal, ao longo deste três séculos. Oportunidade de diáspora foram as conquistas portuguesas do norte de África e, sobretudo, o Índico, o Brasil e a América espanhola, antes da penetração nestes territórios do Tribunal do Santo Ofício. Depois do estabelecimento deste, estas regiões mostravam-se tão perigosas quanto o reino, para o cristão novo.

O comércio com a vizinha Espanha ou com as regiões mais longínquas da Europa, como Antuérpia, na Flandres, ou Amesterdão e Hamburgo na Europa do norte a que se juntaria Londres, possibilitou-lhes, à semelhança do que acontecia com o trato no Mediterrâneo, cristão e turco, a saída sem regresso ou com um retorno, após uma ausência mais ou menos longa, com passagem ou não pelo judaísmo.

A opção pela religião judaica, a permanência na judiaria, o uso do sinal, a ida à sinagoga, a circunscisão e a tomada do nome judeu significavam a impossibilidade de voltar ao reino, quer como cristãos, quer como judeus. O regresso implicava a "expiação» voluntária com a auto apresentação num dos tribunais inquisitoriais, ou o medo da denúncia, feita aos inquisidores por cristãos, geralmente cristãos novos, que os conheceram e com eles comunicaram o judaísmo, em terras de infiéis ou noutras partes da cristandade, apesar das diversas identidades assumidas 
quando do regresso ou passagem temporária por um dos reinos da $\mathrm{Pe}$ nínsula Ibérica.

A diáspora cristã nova reflectiu, assim, vários aspectos de uma mesma realidade:

- que partiram para, em liberdade, poderem regressar à religiãoancestral e à sua identidade histórica como «povo de Deus» a caminho da Terra da Promissão;

- os que, preferindo o exílio, continuaram a viver como cristãosem terras da cristandade, longe da Inquisiççao peninsular;

- os que, perseguidos pelo Santo Ofício, eram enviados pelas suasfamílias para o estrangeiro, mantendo longe do reino os laços familiares, muitas vezes como representantes de sociedades comerciais e financeiras, sedeadas em Portugal ou/e na Espanha.

\section{CONCLUSÃO}

Numa síntese histórica sobre os judeus e cristãos novos portugueses muito mais poderia ser dito e abordado, até de modo mais desenvolvido, apesar de as investigações sobre os cristãos novos se encontrarem nestes últimos anos, numa fase de franco crescimento e inovação.

No entanto, esta síntese não ficaria concluída sem uma breve referência às pequenas comunidades criptojudaicas ainda existentes e quase em vias de extinção, quer em Trás-os-Montes, quer na Beira interior. De todas, Belmonte é a mais conhecida e mais povoada. Aqui, observa-se hoje à penetração do judaísmo e ao abandono de todas aquelas tradições religiosas e de costumbes, miscigenadas, por vezes, de cristianismo, que fizeram de Belmonte uma comuridade singular. Histórica e etnograficamente seria lamentável que, mais uma vez por hermetismo, desaparecesse algo que é, queiramos ou não, um documento vivo de um património histórico português e judeu, como esta oração do Pai Nosso:

«Senhor que estais nas alturas,

por vossos altos favores,

vos chamam os pecadores,

Pai Nosso.

A vós Senhor como posso, o vosso nome invocarei, pois decerto eu bem sei que estais no céu.

Amparai, Senhor, um réu, 
que muito ver vos deseja, que o vosso nome seja santificado.

Eternamente sejais louvado por tais modos,

a uma voz digamos todos:

seja!

Do dizer que ninguém seja, nem o mais de vos louvar.

Só deve triunfar

o vosso nome.

Matai-nos a nossa fome,

Com o bem da vossa mão, e do céu, meu Deus,

o pão venha a nós.

Amparai-nos sempre vós, dando-nos pão e mais pão, e por fim, em conclusão,

o vosso reino.

Fazei que seja vosso esse reino da verdade, sempre a vossa vontade seja feita.

Quando dermos conta estreita, convosco meu Deus me veja, para perdoar-me seja a vossa vontade.

Dai-nos lá, na eternidade, a vossa vista um lugar, já que andamos a peregrinar assim na terra.

É assim que se desterra um pesar com tal prazer, pois mehol lugar não pode haver como no céu.

Em tempo algum seja réu, por culpas que não cometi, a todos dai, como a mim, o pão nosso.

Eu prometo ser tão vosso, que por vós morrerei, sempre vos louvarei cada dia.

Dai-nos prazer e alegria, com poderes da vossa mão, 
e a todos o perdão

nos dai hoje ${ }^{3}$.

\section{BIBLIOGRAFIA}

A bibliografia que apresentamos não pretende ser exaustiva. Inserimola como fonte documental e escrita da síntese que apresentámos, além de ser o que há de mais recente sobre esta matéria, em Portugal.

AzeVEDo, Elvira C., O sefardismo na cultura portuguesa. Porto, ed. Paisagem, 1974.

CANelo, David A., Os últimos criptojudeus em Portugal. Belmonte 1987.

Coelho, António Borges, Inquisição de Évora. Dos primórdios a 1668. Ed. Caminho, 1987, 2 vols.

Ferro, María José P., Os judeus em Portugal no século XIV. IAC, 1970 (2. ${ }^{\circledR}$ ed., ed. Guimarães, 1979, esgotada)

GouveIA, A. Andrade de, Garcia d'Orta e Amato Lusitano na ciência do seu tempo. ICALP, 1985.

Inquisição, Comunicações apresentadas ao $1 .^{\circ}$ Congresso Luso-Brasileiro sobre Inquisição.

Gulbenkian 1987, 3 vols.

Legado cultural de Judeus e Mouros. Lisboa, Instituto Oriental, UNL, 1991.

LeROY, Béatrice, Les Menir. Une famille sepharade a travers les siècles. Paris, CNRS, 1985.

LIPINER, Elias, O tempo dos judeus segundo as ordenações do reino. S. Paulo 1982.

- Gaspar da Gama, um converso na frota de Cabral. Rio de Janeiro 1987.

MAGALHĀES, J. Romero de, "Em busca dos tempos da Inquisição (1573-1615)», sepág. da Revista de História das Ideias. Coimbra 1987, vol. 9.

MEA, Elvira de Azevedo, Sentenças da Inquisição de Coimbra em metropolitanos de D. Frei Bartolomeu dos Mártires (1567-1582). Por to 1982.

METZGER, Thérèze, Les manuscrits hébreux décorés à Lisbonne dans les dernières décennies du XVe siècle. Paris, Gulbenkian, 1984.

Revah, Y., Études Portugaises. Paris, Gulbenkian 1975.

Salomon, H. P., Portrait of a new Christian Fernão Álvares de Melo (1569-1632). Paris, Gulbenkian 1982.

SWETSCHINSKE, D., The Portuguese Jewish merchants of seventeenth century Amsterdam: a social profile. UMI Dissertation, 1988.

Tavares, María José P. Ferro, Os judeus em Portugal no século XV. Lisboa, UNL, 1982, vol. I; INIC, 1985, vol. II.

-, Judaísmo e Inquisição. Ed. Presença, 1987.

-, Los Judios en Portugal. Madrid, eds. Mapfre.

Yerushalmi, Yosef, De la cour d'Espagne au ghetto italien. Fayard 1987.

Zoratrini, Pier Cesare, «Processi del S. Uffizio di Venezia contro ebrei e giudaizzanti», in Storia dellébraismo in Italia. Florença 1984, vols. V, VI, VII e X. 155.

Augusto Canelo, David, Os últimos criptojudeus em Portugal. Belmonte 1987, págs. 154- 
